\title{
Exploring Online Brand Personality of Ghanaian Universities
}

\author{
Rhodalene Amartey \\ Ghana Institute of Journalism, Ghana. P. O. Box 667, Accra
}

\begin{abstract}
The aim of this study is analyse the brand personality of websites of Universities in Ghana. The focus was on the brand personality portrayed on their websites. Aaker's (1997) model served as the conceptual framework. The model has five dimensions; competence, excitement, ruggedness, sincerity and sophistication. The contents of 65 accredited universities with functional websites in Ghana were analysed. All the universities have accreditation from the Ghana National Accreditation Board. Content analysis was the research method adopted. The analysis revealed that the universities portray the following personality traits or attributes on their websites; competence, outstanding, scientific, staunch, unfaltering, thorough, exciting, freshness, inventive, risky, challenge, dangerous, difficult, rigorous, tricky, unrestrained, accurate, authentic, compassion, decent, realistic, charismatic, distinguished, graceful, magnificent.
\end{abstract}

Keywords: Brand personality, branding, content analysis, Universities in Ghana

DOI: $10.7176 / \mathrm{NMMC} / 77-04$

\subsection{Introduction}

The survival of a university partly depends on student population growth, external stakeholders and perception of the university's brand. (Watkins \& Gonzenbach, 2013). The power of branding has been recognized in the corporate world. Branding strategies and concepts such as brand personality, brand loyalty, brand love, brand authenticity, brand equity and brand awareness have been utilized in corporate communication and marketing communication by many firms (Keller 1993). However, very little is known about how universities utilize these branding concepts in their communication. According to Watkins \& Gonzenbach (2013) "for universities to fully utilize the power that comes with successful branding, more research is needed, specifically related to the branding efforts of service sector entities (p. 15). In this era of competition among universities, they cannot afford to forgo branding and how to communicate their brand personality. Boyle and Magnusson, (2007) asserted that "understanding the content and structure of brand knowledge is important because they influence what comes to mind when a consumer thinks about a brand" (p. 2).

An understating of how students and external stakeholders of universities engage brands can enable the universities to create and communicate personalities that resonate the core values of the universities as well as their strengths. Harris (2009) postulated that, '...accounting for individual perceptions - and ultimately decision making -presents a real challenge when adapting branding strategies used for commodities ...' (p. 25). In this view, it can be said that universities are faced with different set of challenges from branding themselves. The need for brands to be unique has been proposed in the literature (Watkins \& Gonzenbach, 2013). Branding gives unique identification to firms and for that matter universities. One of the branding strategies that universities can use to distinguish themselves is brand personality. Brand personality has the potentials of creating and maintaining a strong relationship between universities and its stakeholders (Blackston, 1993). The aim of this study is to analyse the brand personality Universities in Ghana communicate on their websites.

\subsection{Literature Review \\ Brand Identity}

Brand identity is the visual and verbal articulation of a brand, including all pertinent design applications, such as logo, business card, letterhead, or packaging (Tan \& Rasiah, 2011), usually includes a tagline and web site (Rowley, 2009), and sometimes interchanged with corporate identity or visual identity (Keller, 2008). Kotler and Keller (2010) gave a comprehensive definition of brand identity as a program that integrates every visual and verbal element of a company's graphic design, including typography, color, imagery, and its application to print, digital media, environmental graphics, and any other conventional or unconventional media. It is a master plan that coordinates every aspect of graphic design material in order to attain and sustain an identifiable image and status in a multinational marketplace of brands. This definition of brand identity appears to be all encompassing including online and offline branding. This is in recognition of the role that technology plays in organizations' marketing and branding strategies.

The essence of brand elements is to identify and differentiate the brand. Keller (2008) identified six criteria for selecting brand elements including: memorability, that is, the ability of the brand to have an element of attention getting; meaningfulness, that is, the brand should communicate meaningfully about the nature of the product; likeability, referring to the fact that customers should find the brand appealing so the brand should be rich in imagery; transferability, referring to the usefulness of the brand depending on the cultural content and the 
unique qualities of the brand element; adaptability, indicating that the more adaptable the brand element is, the easier it is to update it. For instance, logos and characters can be updated to appear more modern and relevant; and protectability, which establishes the extent to which the branch element is protectable both in the legal and competitive sense. Keller however failed to indicate whether these criteria are relevant in all situations and the weight to place on each criterion. It is important however to acknowledge the usefulness of these criteria in the selection of appropriate brand elements.

\section{Brand Personality}

The concept of brand personality features prominently in influential descriptions of brand management and brand theory (e.g., Aaker, 1996; Keller, 2003; Haugtvedt et al., 2008). Brand personality is argued to play an important role in brand positioning (van Rekom, Jacobs, \& Verlegh, 2006) and to play an essential role in brand attachment because consumers seek brands that reflect their self-images (Malar et al., 2011). Consequently, researchers have proposed selfreport scales to measure brand personality as a set of aspects or dimensions (e.g., Aaker, 1996; Geuens et al., 2009). These scales differ in terms of the number and choice of adjectives they use. Although the fifteen-item Aaker scale is the most prominent, Geuens et al. (2009) critique it for its loose definition of brand personality and the non- generalizability and the non-replicability of its factor structure.

Brand personality refers to "the set of human characteristics associated with a brand" (Aaker 1997, p. 347). Contrary to performance-oriented product attributes, brand personality appears to be representative/selfexpressive oriented (Keller, 2008; Fennis \& Pruyn, 2007). Moreover, it has been suggested that brand personality facilitates a consumer to articulate him/herself

(Belk, 1988), an ideal self (Malhotra, 1988), or exact aspects of the self (Kleine, et al. 1993). Additionally, this concept is an essential determinant of consumer preference and usage (Biel, 1993). Any direct/indirect contact that the consumer has with a brand can influence brand personality (Plummer, 1985). Brand's user imagery is shaped by direct influences or "the set of human characteristics associated with the typical user of a brand" (Aaker, 1997: 348), the firm's workers and/or boss, and the brand's endorsers. On the other hand, the indirect influences contain product-related features, product category relationships, brand name, mark or emblem, and other marketing mix elements (Batra, Lehmann, \& Singh, 1993). Customers tend to select and use brands with various salient personality dimensions to highlight certain aspects of their own personality in various situational contexts (Aaker, 1999; Helgeson \& Supphellen, 2004).

According to Sung and Tinkham (2005), brand personality is a hypothetical construct developed by consumers and it differs from human personality. Individuals possess the human personality traits composed of implicit (perceived) and actual (objective) components, independent of the perceivers' characterization. In contrast, no objective personality traits exist in brand. Aaker, Fournier, and Brasel (2004) note that as the connection between brand and the customer interacts, the personality traits have direct influence on this interaction. Customer

Perceived Value Customer perceived value is a critical notion in the marketing literature (Hansen, Samuelsen, \& Silseth, 2008). Specifically, customer perceived value in commerce marketplace is defined as "the trade-off between the multiple benefits and sacrifices of a supplier's offering, as perceived by key decision-makers in the customer's organisation and taking into consideration the available alternative suppliers' offerings in a specific use situation" (Eggert \& Ulaga, 2002, p. 110).

Three notable elements exist in this definition: (1) the multiple components of value, (2) the subjectivity of value perceptions, and (3) the importance of competition "e (Eggert \& Ulaga, 2002: 109). Ulaga and Eggert (2006) advance the trade-off notion and focus on the multidimensional nature of benefits and sacrifices rather than tangibles. First of all, the multiple benefits refer to a mixture of product/service attributes and/or technological support available related to a specific use condition (Monroe, 1990) and occasionally illustrated in monetary forms (Anderson, Jain, \& Chintagunta, 1993). Second, customers ${ }^{\text {ee }}$ perceived value is subjective, not objective, in nature (Kortge \& Okonkwo, 1993). In other words, different customers may have a variety of perceived values for the same product/service. Third, customers' perceived value is closely tied with competition in the marketplace. Competitors generate sustainable competitive advantage by means of bringing a better trade-off between utilities and sacrifice in a merchandise/service.

It is noteworthy that customer perceived value is not only a take factor (i.e., the benefits that a purchaser obtains from the vendor's contribution) but also a give factor (i.e., the buyer's costs of receiving the offering) (Dodds, 1991). Much of the precedent studies identify product quality as the primary take factor and price as the give factor (Grewal, Monroe, \& Krishnan, 1998). In addition, service is also a logical driver of perceived valuee (Parasuraman \& Grewal, 2000: 169). Sellers provide outstanding sales services in order to increase the benefits perceived by the buyer and to decrease the buyer's non-monetary costs, such as time, effort, and mental stress ${ }^{\text {ee }}$ (Parasuraman \& Grewal, 2000: 169). Marketing practitioners and academicians concern how customers perceive and evaluate the value of products and services (Boshoff \& Gray, 2004; Ulaga \& Eggert, 2006; Naidoo \& Leonard, 2007). 
Only a few researchers, such as Plummer (1985) and David Aaker (1996), have pointed out the importance of brand personality in building competitive advantage and brand loyalty. Recently, Jennifer Aaker (1997) presented the empirical results of her research on the measurement of brand personality. In short, the issues of why and how brand personalities affect consumers' brand loyalty have not been addressed. The study reported here borrowed the methodology developed by Aaker (1997) to measure some dimensions of brand personality. When there is a fit between brand personality and a consumer's self-expression, the consumer may consider a brand as a person, or even a companion. In the real world, this kind of relationship is found between brand and human (Fournier, 1998). Sometimes, the human characteristics attached to a certain brand are used to express one's own image or personality.

Aaker (1997), after realizing the need for further empirical research, developed a new measurement scale for measuring brand personality along five dimensions, extracted from her research. The five dimensions were sincerity, excitement, competence, sophistication, and ruggedness which served as the foundation of theory building with regards to the use of brands symbolically.

A general misconception exists that personality can only apply to human beings and products (Leen, Ramayah \& Omar, 2010). However, recent website study has begun to address the personality issue (Chen \& Rodgers, 2006). Consumers' perceptions of website personality are one of the most critical factors that influence their decision making, including their selection process. Literature suggest that the creation of a unique website personality profile enables marketers to differentiate their brands from its competitors' (Murphy \& Moscardo, 2007), which helps to improve consumers' experiences and their post-visit evaluations (Papadimitriou, Apostolopoulou, \& Kaplanidou, 2015). Website personality has therefore gained significant attention from tourism scholars; however, this thesis assesses how university can build website personality. This study therefore adopts Opoku et al (2006) development from Aaker's (1997) brand personality dictionary to describe the various websites. They are as: (1) excitement (traits such as daring, spirited and imaginative); (2) sincerity (wholesome, downto-earth and honest); (3) competence (reliable, intelligent and successful); (4) sophistication (glamorous, upper class and charming); and (5) ruggedness (outdoorsy, masculine and tough).

Online branding environment should also communicate the brand personality of their products and service to customers (Rutter, Roper, \& Lettice, 2016). According to Leen, Ramayah and

Omar (2010, p. 964), "a general misconception exists that personality can only apply to human beings". However, recent studies have shown that online branding personality can also exist in the online branding (Shobeiri, Laroche \& Mazaheri, 2013; Chi, Pan, \& Del Chiappa, 2018). A distinctive brand personality can help to create a set of unique and favourable online branding environment associations in consumer memory, shaping and improving brand equity (Johnson, Soutar \& Sweeney, 2000; Phau \& Lau 2000).

Several factors have also been identified as influencing the evolution of online branding (Murphy \& Sharl, 2007). However, to develop a university online branding environment, the three constructs under study: brand and website features; dialogic principles; and brand personality must be integrated smoothly to raise the image of the universities and to achieve a concerted effort by gaining competitive advantage over other higher education. Against this backdrop, this study seeks to investigate the brand personality that universities in Ghana are communicating on their websites.

\subsection{Methodology}

This study used content analysis to explore the brand personality that universities in Ghana are communicating on their websites. Content analysis has been defined variously. The definitions in the literature include the following;

"a research method for the subjective interpretation of the content of text data through the systematic classification process of coding and identifying themes or patterns"

(Hsieh \& Shannon, 2005, p.1278),

- "an approach of empirical, methodological controlled analysis of texts within their context of communication, following content analytic rules and step by step models, without rash quantification" (Mayring, 2000, p.2), and

- "any qualitative data reduction and sense-making effort that takes a volume of qualitative material and attempts to identify core consistencies and meanings" (Patton, 2002, p.453).

These definitions show that content analysis stresses on an integrated perspective of speech/texts and their specific contexts. The contents that can be analyzed include, text, photos, videos, and audios.

The study involves 65 accredited universities with functional websites in Ghana. The researcher visited the websites of the universities and extracted texts for analysis. Aaker's (1997) brand personality framework was adopted to analyze the contents of the websites. The five dimension of Aaker's framework are as follows;

- $\quad$ Sincerity (down to earth, honest, wholesome, cheerful)

- Excitement (daring, spirited, imaginative, up to date) 
- Competence (reliable, intelligent, successful)

- Sophistication (upper class, charming)

- Ruggedness (outdoorsy, tough)

Attributes or personality traits available on the websites were marked present while those that are not available on the websites were marked absent. Frequency and percentages were used to present the findings.

\subsection{Presentation of Findings}

The brand personality attributes that were available on the websites are presented as follows; Competence

\begin{tabular}{ccc}
\hline Response & Frequency & Percent \\
\hline Absent & 7 & 10.8 \\
Present & 58 & 89.2 \\
Total & 65 & 100 \\
\hline
\end{tabular}

\section{Table 1}

The table above shows the representation of responses for the brand personality of the various university websites. Out of the total of 65 websites assessed, 58 representing 89.2 percent had the level of competence present whilst 7 representing 10.8 percent did not have.

Outstanding

\begin{tabular}{ccc}
\hline Response & Frequency & Percent \\
\hline Absent & 8 & 12.3 \\
Present & 57 & 87.7 \\
Total & 65 & 100.0 \\
\hline
\end{tabular}

\section{Table 2}

The above table recorded the representation of responses for the brand personality of the various university websites. Out of the total of 65 websites assessed, 57 representing 87.7 percent had the level of outstanding present whilst 8 representing 12.3 percent had absent.

Scientific

\begin{tabular}{ccc}
\hline Response & Frequency & Percent \\
\hline Absent & 11 & 16.9 \\
Present & 54 & 83.1 \\
Total & 65 & 100.0 \\
\hline
\end{tabular}

\section{Table 3}

The above table recorded the representation of responses for the brand personality of the various university websites. Out of the total of 65 websites assessed, 54 representing 83.1 percent had the level of scientific present whilst 11 representing 16.9 percent had absent. 
Staunch

Response Frequency Percent

$\begin{array}{ccc}\text { Absent } & 10 & 15.4 \\ & & \\ \text { Present } & 55 & 84.6 \\ \text { Total } & 65 & \end{array}$

100.0

\section{Table 4}

The above table recorded the representation of responses for the brand personality of the various university websites. Out of the total of 65 websites assessed, 55 representing 84.6 percent had the level of staunch present whilst 10 representing 15.4 percent had absent.

Unfaltering

\begin{tabular}{ccc}
\hline Response & Frequency & Percent \\
\hline Absent & 7 & 10.8 \\
Present & 58 & 89.2 \\
Total & 65 & 100.0 \\
\hline
\end{tabular}

\section{Table 5}

The above table recorded the representation of responses for the brand personality of the various university websites. Out of the total of 65 websites assessed, 58 representing 89.2 percent had the level of unfaltering present whilst 7 representing 10.3 percent had absent.

Thorough

Response Frequency Percent

\begin{tabular}{ccc}
\hline Absent & 8 & 12.3 \\
Present & 57 & 87.7 \\
Total & 65 & 100.0 \\
\hline
\end{tabular}

\section{Table 6}

The above table recorded the representation of responses for the brand personality of the various university websites. Out of the total of 65 websites assessed, 57 representing 87.7 percent had the level of thorough present whilst 8 representing 12.3 percent had absent.

Exciting

\begin{tabular}{ccc}
\hline Response & Frequency & Percent \\
\hline Absent & 9 & 13.8 \\
Present & 56 & 86.2 \\
Total & 65 & 100.0 \\
\hline
\end{tabular}

\section{Table 7}

The above table recorded the representation of responses for the brand personality of the various university websites. Out of the total of 65 websites assessed, 56 representing 86.2 percent had the level of excitement present whilst 9 representing 13.8 percent had absent. 


\begin{tabular}{ccc}
\hline Absent & 9 & 13.8 \\
Present & 56 & 86.2 \\
Total & 65 & 100.0 \\
\hline
\end{tabular}

\section{Table 8}

The above table recorded the representation of responses for the brand personality of the various university websites. Out of the total of 65 websites assessed, 57 representing 87.7 percent had the level of freshness present whilst 8 representing 12.3 percent had absent.

Inventive

\begin{tabular}{ccc}
\hline Response & Frequency & Percent \\
\hline Absent & 11 & 16.9 \\
Present & 54 & 83.1 \\
Total & 65 & 100.0 \\
\hline
\end{tabular}

\section{Table 9}

The above table recorded the representation of responses for the brand personality of the various university websites. Out of the total of 65 websites assessed, 54 representing 83.1 percent had the level of inventive present whilst 11 representing 16.9 percent had absent.

\begin{tabular}{ccc} 
Risky & & \\
\hline Response & Frequency & Percent \\
\hline Absent & 46 & 70.8 \\
Present & 19 & 29.2 \\
Total & 65 & 100.0 \\
\hline
\end{tabular}

\section{Table 10}

The above table recorded the representation of responses for the brand personality of the various university websites. Out of the total of 65 websites assessed, 46 representing 70.8 percent did not have the level of risky present whilst 19 representing 29.2 percent had it present.

Challenge

\begin{tabular}{ccc}
\hline Response & Frequency & Percent \\
\hline Absent & 38 & 58.5 \\
Present & 27 & 41.5 \\
Total & 65 & 100.0 \\
\hline
\end{tabular}

\section{Table 11}

The above table recorded the representation of responses for the brand personality of the various university websites. Out of the total of 65 websites assessed, 38 representing 58.5 percent did not have the level of risky present whilst 27 representing 41.5 percent had it present. Dangerous 


\begin{tabular}{ccc} 
Response & Frequency & Percent \\
\hline Absent & 60 & 92.3 \\
Present & 5 & 7.7 \\
Total & 65 & 100.0
\end{tabular}

\begin{tabular}{|c|c|c|}
\hline \multicolumn{3}{|c|}{$\begin{array}{l}\text { Table 12 } \\
\text { The above table recorded the representation of responses for the brand personality of the various university } \\
\text { websites. Out of the total of } 65 \text { websites assessed, } 60 \text { representing } 92.3 \text { percent did not have the level of } \\
\text { dangerous present whilst } 5 \text { representing } 7.7 \text { percent had it present. }\end{array}$} \\
\hline \multicolumn{3}{|l|}{ Difficult } \\
\hline Response & Frequency & Percent \\
\hline Absent & 56 & 86.2 \\
\hline Present & 9 & 13.8 \\
\hline Total & 65 & 100.0 \\
\hline
\end{tabular}

\section{Table 13}

The above table recorded the representation of responses for the brand personality of the various university websites. Out of the total of 65 websites assessed, 56 representing 86.2 percent did not have the level of difficult present whilst 9 representing 13.8 percent had it present.

Rigorous

\begin{tabular}{ccc}
\hline Response & Frequency & Percent \\
\hline Absent & 42 & 64.6 \\
Present & 23 & 35.4 \\
Total & 65 & 100.0 \\
\hline
\end{tabular}

\section{Table 14}

The above table recorded the representation of responses for the brand personality of the various university websites. Out of the total of 65 websites assessed, 42 representing 64.6 percent have the level of rigorous absent whilst 23 representing 35.4 percent had it present.

Tricky

\begin{tabular}{ccc}
\hline Response & Frequency & Percent \\
\hline Absent & 59 & 90.8 \\
\hline Present & 6 & 9.2 \\
Total & 65 & 100.0 \\
\hline
\end{tabular}

\section{Table 15}

The above table recorded the representation of responses for the brand personality of the various university websites. Out of the total of 65 websites assessed, 59 representing 90.8 percent have the level of tricky absent whilst 7 representing 9.2 percent had it present. 
Unrestrained

\begin{tabular}{ccc}
\hline Response & Frequency & Percent \\
& & 92.3 \\
Absent & 60 & 7.7 \\
Present & 5 & 100.0 \\
Total & 65 & \\
\hline
\end{tabular}

\section{Table 16}

The above table recorded the representation of responses for the brand personality of the various university websites. Out of the total of 65 websites assessed, 60 representing 92.3 percent have the level of unrestrained absent whilst 5 representing 7.7 percent had it present.

Accurate

\begin{tabular}{ccc}
\hline Response & Frequency & Percent \\
Absent & 9 & 13.8 \\
Present & 56 & 86.2 \\
Total & 65 & 100.0 \\
\hline
\end{tabular}

\section{Table 17}

The above table recorded the representation of responses for the brand personality of the various university websites. Out of the total of 65 websites assessed, 56 representing 86.2 percent had the level of accurate present whilst 9 representing 13.8 percent had absent.

Authentic

\begin{tabular}{ccc}
\hline Response & Frequency & Percent \\
& & 10.8 \\
Absent & 7 & 89.2 \\
Present & 58 & 100.0 \\
Total & 65 & \\
\hline
\end{tabular}

\section{Table 18}

The above table recorded the representation of responses for the brand personality of the various university websites. Out of the total of 65 websites assessed, 56 representing 86.2 percent had the level of authentic present whilst 9 representing 13.8 percent had absent.

Compassion

\begin{tabular}{ccc}
\hline Response & Frequency & Percent \\
\hline Absent & 7 & 10.8 \\
Present & 58 & 89.2 \\
Total & 65 & 100.0 \\
\hline
\end{tabular}

\section{Table 19}

The above table recorded the representation of responses for the brand personality of the various university websites. Out of the total of 65 websites assessed, 58 representing 89.2 percent had the level of compassion present whilst 7 representing 10.8 percent had absent. 


\begin{tabular}{ccc} 
Decent & & \\
\hline Response & Frequency & Percent \\
\hline Absent & 7 & 10.8 \\
\hline Present & 58 & 89.2 \\
Total & 65 & 100.0 \\
\hline
\end{tabular}

\section{Table 20}

The above table recorded the representation of responses for the brand personality of the various university websites. Out of the total of 65 websites assessed, 58 representing 89.2 percent had the level of Decent present whilst 7 representing 10.8 percent had absent.

Realistic

\begin{tabular}{ccc}
\hline Response & Frequency & Percent \\
\hline Absent & 9 & 13.8 \\
Present & 56 & 86.2 \\
Total & 65 & 100.0 \\
\hline
\end{tabular}

\section{Table 21}

The above table recorded the representation of responses for the brand personality of the various university websites. Out of the total of 65 websites assessed, 56 representing 86.2 percent had the level of realistic present whilst 7 representing 13.8 percent had absent.

Charismatic

\begin{tabular}{ccc}
\hline Response & Frequency & Percent \\
\hline Absent & 8 & 12.3 \\
Present & 57 & 87.7 \\
Total & 65 & 100.0 \\
\hline
\end{tabular}

\section{Table 22}

The above table recorded the representation of responses for the brand personality of the various university websites. Out of the total of 65 websites assessed, 57 representing 87.7 percent had the level of charismatic present whilst 8 representing 12.3 percent had absent.

Distinguished

\begin{tabular}{ccc}
\hline Response & Frequency & Percent \\
\hline Absent & 8 & 12.3 \\
Present & 57 & 87.7 \\
Total & 65 & 100.0 \\
\hline
\end{tabular}

\section{Table 23}

The above table recorded the representation of responses for the brand personality of the various university websites. Out of the total of 65 websites assessed, 57 representing 87.7 percent had the level of distinguished present whilst 8 representing 12.3 percent had absent. 
Graceful

\begin{tabular}{ccc}
\hline Response & Frequency & Percent \\
\hline Absent & 8 & 12.3 \\
Present & 57 & 87.7 \\
Total & 65 & 100.0 \\
\hline
\end{tabular}

\section{Table 24}

The above table recorded the representation of responses for the brand personality of the various university websites. Out of the total of 65 websites assessed, 57 representing 87.7 percent had the level of graceful present whilst 8 representing 12.3 percent had absent.

Magnificent

\begin{tabular}{ccc}
\hline Response & Frequency & Percent \\
\hline Absent & 9 & 13.8 \\
Present & 56 & 86.2 \\
Total & 65 & 100.0 \\
\hline
\end{tabular}

\section{Table 25}

The above table recorded the representation of responses for the brand personality of the various university websites. Out of the total of 65 websites assessed, 57 representing 86.2 percent had the level of magnificent present whilst 8 representing 13.8 percent

\subsection{Discussions and Conclusions}

Over the past 2 decades, brand personality has attracted much attention from researchers. The interest in the topic is partly due to the strategic importance of brand personality. As noted by Watkins and Gonzenbach (2013), brand personality enables universities to differentiate themselves from each other and also survive stiff competition. In this study, the researcher explored the personality attributes or traits that universities in Ghana communicate on their websites. It was ascertained that the universities communicate the following personality attributes or traits; competence, outstanding, scientific, staunch, unfaltering, thorough, exciting, freshness, inventive, risky, challenge, dangerous, difficult, rigorous, tricky, unrestrained, accurate, authentic, compassion, decent, realistic, charismatic, distinguished, graceful, magnificent. From the findings, it can be said that the universities portray certain attributes of human beings. This finding confirms Aaker's definition of brand personality.

Aaker defines the brand personality as "the set of human characteristics associated with a given brand" (Aaker 1997). From the findings, it can be inferred that brand personality can help universities to comprehend the perceptions and attitude of the students and external stakeholders toward the brand as according to Murphy and Moscardo, (2007) a consumer's perception of website personality is one of the most critical factors that influence their decision making, including their selection process.

Based on the findings the researcher recommends that the universities should invest in brand communication since their survival partly depend on that. Furthermore, they need to develop and communicate the personality they want their external stakeholders to perceive. It appears that many of the universities do not have a branding strategy in place since the findings did not show that the universities are consistent in communicating their brand personality

\section{References}

Harris, M. S. (2009). Message in a bottle: University advertising during bowl games. Innovation Higher Education, 33, 285-296.

Blackston, M. (1993). Beyond brand personality: Building relationships. In D. A. Aacker \& A. Biels (Eds.), Brand equity and advertising (pp. 113-124). Hillsdale, NJ: Lawrence Erlbaum Associates.

Boyle, B. A., \& Magnusson, P. (2007). Social identity and brand equity formation: A comparative study of collegiate sports fans. Journal of Sports Management, 21, 497-520.

Keller, K. (1993). Conceptualizing, measuring, and managing customer-based brand equity. The Journal of 
Marketing, 57(1), 1-22. Retrieved from http://www.jstor.org/stable/1252054

Watkins, B. A., \& Gonzenbach, W. J. (2013). Assessing university brand personality through logos: An analysis of the use of academics and athletics in university branding. Journal of Marketing for Higher Education, 23(1), 15-33.

\section{PROFILE OF MRS RHODALENE AMARTEY}

Mrs. Rhodalene Amartey is a seasoned lecturer and a researcher with an insatiable desire for knowledge and ready to impart to others. She holds a Bachelor's degree in Sociology and a Masters' degree in Business Administration (Marketing Option) respectively from the University of Ghana. She also holds a professional marketing qualification from the Chartered Institute of Marketing,

UK. Currently, she is a final year Doctoral student $(\mathrm{PhD})$ in Business Administration at the Accra Institute of Technology, a private university affiliated with the Open University in Malaysia 